\title{
BIO-FLOCCULATION AND ANTIMICROBIAL ACTIVITIES OF POWDERED MORINGA OLEIFERA (LAM) SEEDS AND ALUM ON DOMESTIC WASTEWATER MICROBIAL CONSORTIA
}

\section{SCI@ELL}

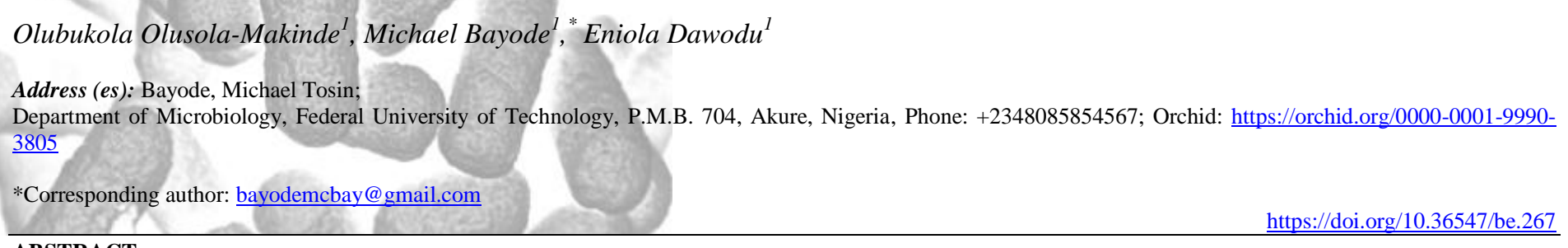
ABSTRACT

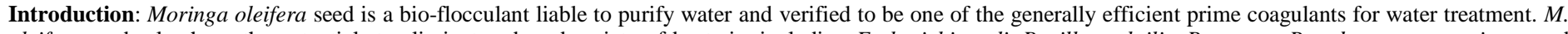

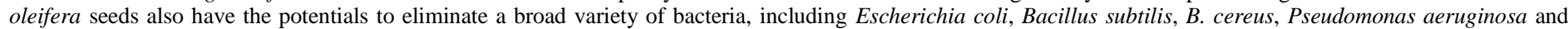
Enterobacter ludwigii, from domestic wastewater.

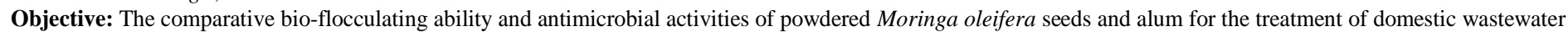
from a university student' hostels were explored.

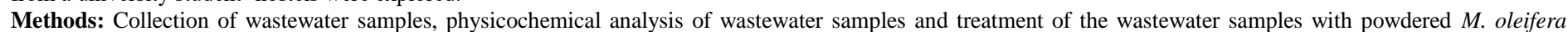

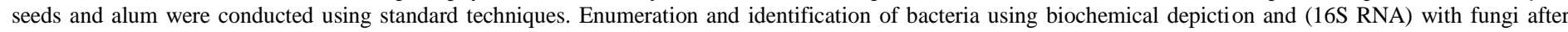
treatment were employed via standard protocols.

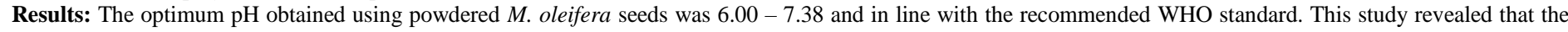

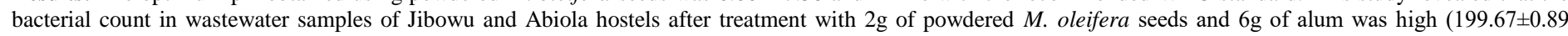

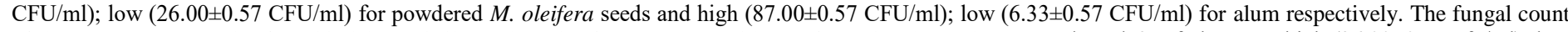

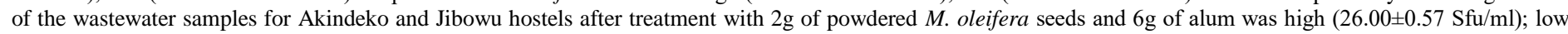

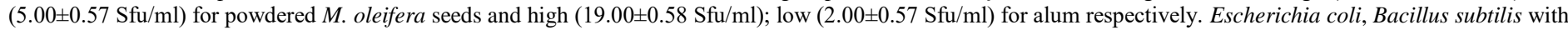
NCBI-certified B. cereus mkbk1, Pseudomonas aeruginosa mkbk 2 and Enterobacter ludwigii mkbk 3 were isolated from the wastewater samples.

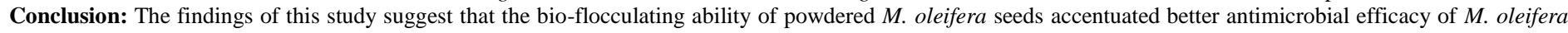
over alum as a proviso to the blend of powdered $M$. oleifera seeds and alum for the treatment of domestic wastewaters.

Keywords: Alum; Antimicrobial; Bio-flocculation; Moringa oleifera; Physicochemical; Wastewater, 16S RNA

\section{INTRODUCTION}

Wastewater is universally labeled as domestic wastewater or industrial wastewater. Domestic wastewater refers to wastewater spawn from nonmanufacturing activities routine in inhabited homes which include sewage (from toilets) and grey water (from bathrooms and kitchens) (Mohamed and Mohamed, 2016). It comprises of human waste (enclosing pathogens), paper, soap, detergent filtrate and food oddments (MEIDW, 2018). Domestic wastewater is the water that has been used by the public and which include all the resources added to the water during its use. It is thus making up of human body wastes (faeces and urine) jointly with the water used for flushing toilets, coupled with the resultant wastewater from delicate washing, laundry, food-making and the cleaning of kitchen paraphernalia (Duncan, 2003).

Boasted by the outcome of innate coagulant reports in Moringa oleifera seeds, several emergent nations have embraced the usage of the plant seed as a pragmatic coagulant in domestic wastewater management on a small scale (Thakur and Choubey, 2014). Katayon et al. (2006) have given an account of the utility of Moringa oleifera seed powder for plummeting low and high turbidity values in surface water.

The coagulation efficiency of $M$. oleifera in relation to the $\mathrm{pH}$ should either be acidic $(<6)$ or should be alkaline $(>11)$, their coagulation efficiency is particularly good due to the domination of positive charges on the amino acids that build the protein molecule as stated by Sasikala and Muthuraman, (2016). Moringa seeds have displayed antimicrobial properties on bacteria in precedence attributing to recombinant protein presence in the seeds with inherent potential to flocculate Gram-positive and Gram-negative bacterial cells. In this case, microbes can be detached by resolving in analogous mode as the elimination of colloids in suitably coagulated and flocculated water. Nonetheless, the seeds may also act unswervingly upon microbes consequently leading to growth reticence. According to Amagloh and Benang, (2009), domestic wastewater treatment tends to depend on the unstable loading dosage concentrations of the $\mathrm{pH}$. Employing intrinsic resources of plant source to elucidate turbid water like domestic aqueous waste is not a novel scheme as opined by Bina, (1991); Folkard and Sutherland, (2001). Amid all the plant materials that have been employed over the years, powder extracted from Moringa oleifera seeds has been demonstrated to be one of the chiefly effectual prime coagulants for domestic wastewater management and thereby compared favourably to alum which is a traditional chemical coagulant for domestic aqueous waste management as stated by Mangale et al. (2012).
Numerous reports have demonstrated that the usage of natural coagulants as an alternative for metal salts like ammonium sulphate in alleviating the hazards allied with chemical coagulants. Precedent studies have found Moringa oleifera seeds to be safe and suggested as an supplementary plus over the chemical treatment of domestic aqueous waste since it is biological and edible (Adeniran et al., 2017).

$M$. oleifera seeds also have the potentials to eliminate a broad variety of grampositive and gram-negative bacteria, algae, from domestic wastewater samples (Akhtar et al., 2007; Suarez et al., 2003). Another antimicrobial property of $M$. oleifera seeds includes total removal of coliform bacteria in contaminated waters as noted by Muyibi and Evison, (1995). A study conducted by Jabeen $\boldsymbol{e t}$ al . (2008) has reported aqueous seed extracts of $M$. oleifera to possess antifungal effects against Fusarium solani and Aspergillus spp. Alum has been reported to comprise antibacterial activity against Gram Positive and Gram negative bacterial consortia including Enterococcus faecalis, E. faecium, Escherichia coli, Klebsiella pneumoniae and Pseudomonas aeruginosa (Putt and Kleber, 2008; Photos-Jones, 2018) from contaminated domestic waters. Antifungal activity of alum has also been detailed against Aspergillus, niger, A. fumigatus, Penicillium spp, Fusarium spp and the likes.

However, quite a few drawbacks such as soaring cost and $\mathrm{pH}$ variations have been evident by using alum (Meneghel et al. 2013). Multifarious reports have accomplished the fact that $M$. oleifera seeds do not elicit any noxious outcome when employed for domestic wastewater treatment (Vikashni et al. 2012; Mangale et al. 2012). Moringa oleifera seed powder filtrate can be utilized straightforwardly in domestic wastewater management (Arnoldsson et al., 2008). The extracted part of $M$. oleifera seed thwarts the growth of coliforms and pathogens (Arnoldsson et al. 2008; Bina et al. 2010; Eman et al. 2014). This entails the diminution of the disinfection criteria in domestic aqueous waste management (Srivastava, 2014; Jabeen et al. 2008).

Domestic wastewater contains an assortment of wastes; which makes the microbial consortia present to proliferate by employing the organic and inorganic substrates therein. Consequently, these types of microbes will have an exact form of features in contrast to bacteria growing in other habitats as stated by Ishak $\boldsymbol{e t}$ al. (2008). Domestic wastewater commonly includes the bacteria consortium of coliforms, clostridia, enterococcus, lacto bacilli, Micrococci, Proteus, Pseudomonas, Streptococcus, Staphylococcus species (Zaved et al., 2008).

Aluminium sulphate (alum) is an inert salt and the extensively used coagulant in domestic wastewater treatment. Nevertheless, the utilization of aluminium salt as coagulant has come under inquiry. Moreover, elevated residues of aluminium 
remnants in the treated aqueous waste have raised apprehension on human wellbeing. Prior investigations have been critical on the intake of huge total of aluminium salt eliciting an up-rise of neurodegenerative maladies (Ahmad et al., 2018). Bala et al. (2011) reported aluminium sulphate had an appreciable antimicrobial activity against E. coli $\mathrm{DH} 5 \alpha$ and Staphylococcus epidermidis NCIMB 12721 which confirms the potential of alum for water disinfection application.

Pathogenic fungi also have a considerable effect on the biology of the domestic wastewater environment as stated by Brown et al. (2012). Fungal members such as Acremonium, Rhodotorula, Candida, Cladosporium, Sporothrix, Geotrichum candidum, Aspergillus, Penicillium, Trichophyton and Scopulariopsis are reported as often occurring fungal genera implicated in domestic wastewater milieu detected using culture-dependent methods as noted by Liu et al. (2017). Hence the purpose of this study is to independently evaluate the bio-flocculation and antimicrobial activities of Moringa oleifera (lam) seeds and alum on domestic wastewater samples collected from Federal University of Technology, Akure male and female students' hostels. This is to prove the bio-flocculating ability of powdered $M$. oleifera seeds and to accentuate the comparative antimicrobial efficacy of powdered $M$. oleifera seeds and alum. The effects of treating the domestic wastewater with $M$. oleifera seed powder and alum with respect to the physicochemical profile of the domestic wastewater samples were also evaluated.

\section{EXPERIMENTAL PROTOCOLS}

\section{Depiction of catchment area}

The study was carried out at male hostels (Akindeko, Abiola, Adeniyi) and female hostels (Jibowu and Jadesola) situated within the vicinity of the Federal University of Technology, Akure, Ondo State, Nigeria (Figure 1). The University is located between latitudes $7^{\circ} 16$ and $7^{\circ} 18 \mathrm{~N}$ and longitudes $5^{\circ} 009$ and $5^{\circ} 011 \mathrm{E}$. It is situated along Akure-Ilesha expressway, with Awule, Ibule and Ilara as the bordering rural communities.

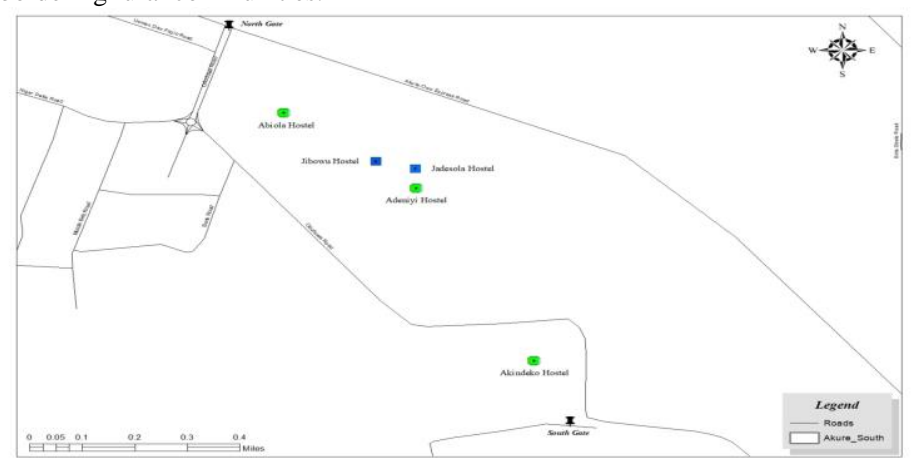

Figure 1 Locality map showing sampling points of male and female hostels in the tertiary study setting

\section{Preparation of M. oleifera seeds powder}

The seeds were obtained from Bodija market in Ibadan, Oyo state. The seeds were dried, manually de-shelled and the seed kernels were homogenized using an electric high power blender (Marlex Electrolyne IS: 250). The powder was stored in a sterile plastic bag and stored in room condition.

\section{Collection and treatment of the wastewater samples}

Domestic wastewater was collected from discharge outlets in students' residential hostels (Jibowu, Jadesola, Akindeko, Adeniyi, Abiola) in Federal University of Technology, Akure which is the area of study. The samples were collected into clean, transparent 5 liter kegs. The samples were collected at the run-off point, where it is released into the environment. The wastewater samples were gently homogenized in $500 \mathrm{ml}$ keg before pouring into sterilized plastic containers, 500 $\mathrm{ml}$ of the collected wastewater specimens was poured into each bowl, powdered $M$. oleifera seeds and crushed (weighted) alum was added to each plastic bowl using varying concentrations ( $2 \mathrm{~g}, 4 \mathrm{~g}$ and $6 \mathrm{~g}$ ). Each bowl was stirred using a stirrer continuously for $5 \mathrm{~min}$ and then allowed to stand for $60 \mathrm{~min}$. Standard pour plate method was used in bacterial characterization with $0.5 \mathrm{ml}$ of the supernatant. The plates were incubated at appropriate temperature and observed after $24 \mathrm{hr}$ for bacteria and $72 \mathrm{hr}$ for fungi enumeration.

Physiochemical analysis of the domestic wastewater samples before and after treatment with M. oleifera seed powder and alum

The wastewater samples were analyzed for physiochemical properties including electrical conductivity, $\mathrm{pH}$ and turbidity before (initial) and after treatment with both $M$. oleifera seeds and alum. Also after treatment, the supernatant gotten from the treated wastewater were also analyzed physico-chemically via the above listed parameters.

A calibrated Crison Conductimeter Basic C30 was used. The conductimeter was switched on and allowed to warm for about 5 minutes. The probe was calibrated using distilled water. The conductivity meter probe was then inserted making sure it did not touch the beaker. The reading was recorded from the LCD display after it had stabilized.

The $\mathrm{pH}$ of the raw wastewater and the supernatants from the treated sample was determined using $\mathrm{pH}$ meter as described by AOAC, (2012). This was done by first standardizing the $\mathrm{pH}$ meter (Hanna multi-parameter $-\mathrm{H} 1-9828$ ) fitted with glass electrodes using buffer solutions of $\mathrm{pH} 4.0$ and $\mathrm{pH}$ 7.0. The electrode was then rinsed with distilled water and immersed into the sample and making sure it did not touch the beaker. The reading was recorded from the LCD display after it had stabilized.

Spectrophotometer (752 p B\&D England) was used to check the turbidity and distilled water was used as reference (to blank the spectrophotometer). The level of difference between the distilled water and the filtrate was used to indicate turbidity levels of the wastewater samples. The spectrophotometer was blanked (or zeroed) using distilled water, about $25 \mathrm{ml}$ of the filtrate was poured into the curvette and the side was clean with a tissue paper before inserting into the spectrophotometer. The absorbance was read at a wavelength of $750 \mathrm{~nm}$. The turbidity of the wastewater samples was displayed on the LCD panel of the instrument in Nephelometric Turbidity Units (NTU). After each reading, the spectrophotometer was calibrated again with the distilled water before being used on the next sample.

\section{Isolation and identification of bacteria from the wastewater samples}

Serial dilution and standard pour plate method using one (1) $\mathrm{ml}$ of $10^{-4}$ diluent of domestic wastewater samples was employed as bacterial organisms were enumerated on nutrient agar (Hi-Media, India) and MacConkey agar (Hi-Media, India) plates as demonstrated by Fawole and Osho, (2001). The bacteria petriplates were incubated for duration of $18-24$ hours at $37^{\circ} \mathrm{C}$. The bacterial colonies were then sub-cultured for identification through molecular analysis. Biochemical confirmatory tests were conducted on the isolated bacteria including; gram reaction, catalase, coagulase, motility, urease, indole, oxidase, citrate and sugar fermentation tests for their identification via comparism with bergey's manual of systematic bacteriology (Don et al., 2006).

\section{Isolation and identification of fungi from the wastewater samples}

Serial dilution and standard pour plate method using one (1) $\mathrm{ml}$ of $10^{-4}$ diluent of domestic wastewater samples was employed as fungal organisms were enumerated on potato dextrose agar (Hi-Media, India) plates as described by Fawole and Osho, (2008). The fungal petri-plates were incubated for duration of 72 hours at $27{ }^{\circ} \mathrm{C}$. The fungal isolates were identified by transferring a mycelia growth on the plates with the aid of sterile needle from a pure culture onto a grease-free glass slide containing a drop of lactophenol cotton blue, the mycelium was placed on the slide, covered with a cover slip and then viewed under the microscope at low power X40 magnification objective.

\section{$16 S$ gene amplification of bacterial isolates from the wastewater samples}

Polymerase chain reaction (PCR)-based identification and characterization of bacterial isolates were carried out with DNA extraction of bacteria isolates according to the technique illustrated by Gurakan et al. (2008). The 16SrRNA gene of the bacteria was amplified using the primer pair 27F-5'AGAGTTTGATCCTGGCTCAG-3', and 1492R 5'GGTTACCTTGTTACGACTT-3'. PCR extension was carried as demonstrated by Sambrook $\boldsymbol{e t}$ al. (2001); the PCR profile used was initial denaturation temperature of $94{ }^{\circ} \mathrm{C}$ for 3 mins, followed by 30 cycles of $94{ }^{\circ} \mathrm{C}$ for $60 \mathrm{sec}, 56{ }^{\circ} \mathrm{C}$ 
for $60 \mathrm{sec}, 72{ }^{\circ} \mathrm{C}$ for 120 seconds and the final extension temperature of $72{ }^{\circ} \mathrm{C}$ for 5 minutes followed by sequencing and genetic make-up blasting via the National centre for biotechnological information (NCBI) server. PCR-sequencing was conducted via DNA Sanger sequencing and data was analyzed by ABI Sequencing Analysis software (version 5.2).

\section{Data analysis}

Analysis of study statistics was carried out using analysis of variance (ANOVA) to determine if significant differences (standard error of mean) exist between the initial, after treatment with $M$. oleifera seeds and after treatment with alum, for each physiochemical parameter $(p \leq 0.05)$ via SPSS (version ' 22$)$.

\section{RESULTS}

Effects of powdered Moringa oleifera seeds and alum on electrical conductivity of domestic wastewater samples

The electrical conductivity $(\mu \mathrm{s} / \mathrm{cm})$ at the point of collection of the wastewater samples from the students' hall of residences was high at $1910.67 \mu \mathrm{s} / \mathrm{cm}$ for Abiola hostel and low at $420.00 \mu \mathrm{s} / \mathrm{cm}$ for Jadesola. The electrical conductivity of $2 \mathrm{~g}$ of powdered M. oleifera seeds was high at $668.33 \mu \mathrm{s} / \mathrm{cm}$ for Abiola hostel and low at $199.00 \mu \mathrm{s} / \mathrm{cm}$ for Jadesola hostel. The electrical conductivity of $4 \mathrm{~g}$ of powdered M. oleifera seeds was high at $701 \mu \mathrm{s} / \mathrm{cm}$ for Abiola hostel and low at $248.33 \mu \mathrm{s} / \mathrm{cm}$. The electrical conductivity of $6 \mathrm{~g}$ of powdered $M$. oleifera seeds was high at $757.33 \mu \mathrm{s} / \mathrm{cm}$ for Abiola hostel and low at $269 \mu \mathrm{s} / \mathrm{cm}$. The electrical conductivity of $2 \mathrm{~g}$ of alum was high at $911.61 \mu \mathrm{s} / \mathrm{cm}$ for Abioa hostel and low at $302.33 \mu \mathrm{s} / \mathrm{cm}$ for Jadesola hostel. The electrical conductivity of $4 \mathrm{~g}$ of alum was high at $1132 \mu \mathrm{s} / \mathrm{cm}$ for Abiola hostel and low conductivity was observed at $347.66 \mu \mathrm{s} / \mathrm{cm}$ for Jadesola hostel. The electrical conductivity of $6 \mathrm{~g}$ of alum was high at $1188.67 \mu \mathrm{s} / \mathrm{cm}$ for Abiola hostel and the least conductivity at 381.67 $\mu \mathrm{s} / \mathrm{cm}$ for Jadesola hostel as observed as illustrated in Table 1.

Table 1 Effects of powdered Moringa oleifera seeds and alum on electrical conductivity of domestic wastewater samples

\begin{tabular}{|c|c|c|c|c|c|c|c|}
\hline \multirow[t]{2}{*}{$\begin{array}{l}\text { School } \\
\text { hostels }\end{array}$} & \multirow[t]{2}{*}{ Initial $(\mu \mathrm{s} / \mathbf{c m})$} & \multicolumn{3}{|c|}{$\begin{array}{l}\text { After treatment with powdered } M \text {. oleifera seeds } \\
\qquad(\mu \mathrm{s} / \mathrm{cm})\end{array}$} & \multicolumn{3}{|c|}{ After treatment with alum $(\mu \mathrm{s} / \mathrm{cm})$} \\
\hline & & $2 \mathrm{~g}$ & $4 \mathrm{~g}$ & $6 \mathrm{~g}$ & $2 g$ & $4 \mathrm{~g}$ & $6 \mathrm{~g}$ \\
\hline Jibowu & $1007.67 \pm 8.88^{\mathrm{g}}$ & $432.33 \pm 1.86^{\mathrm{a}}$ & $493.67 \pm 0.88^{b}$ & $535.33 \pm 0.64^{\mathrm{c}}$ & $692.33 \pm 1.45^{\mathrm{d}}$ & $756.33 \pm 0.33^{\mathrm{e}}$ & $822.00 \pm 1.16^{\mathrm{T}}$ \\
\hline Jadesola & $420.00 \pm 1.16^{\mathrm{g}}$ & $199.00 \pm 0.58^{\mathrm{a}}$ & $248.33 \pm 0.33^{\mathrm{b}}$ & $269.00 \pm 0.58^{\mathrm{c}}$ & $302.33 \pm 1.45^{\mathrm{d}}$ & $347.66 \pm 1.45^{\mathrm{e}}$ & $381.67 \pm 1.67^{\mathrm{f}}$ \\
\hline Akindeko & $649.67 \pm 0.88^{\mathrm{g}}$ & $271.67 \pm 2.03^{\mathrm{a}}$ & $356.00 \pm 0.58^{\mathrm{b}}$ & $376.67 \pm 0.88^{c}$ & $445.00 \pm 2.52^{\mathrm{d}}$ & $547.67 \pm 1.45^{\mathrm{e}}$ & $573.00 \pm 2.08^{\mathrm{f}}$ \\
\hline Adeniyi & $1464.00 \pm 0.58^{\mathrm{g}}$ & $565.00 \pm 1.53^{\mathrm{a}}$ & $630.33 \pm 0.88^{\mathrm{b}}$ & $701.00 \pm 2.08^{\mathrm{c}}$ & $852.00 \pm 1.16^{\mathrm{d}}$ & $948.33 \pm 0.88^{\mathrm{e}}$ & $1100.33 \pm 1.45^{\mathrm{f}}$ \\
\hline Abiola & $1910.67 \pm 1.76^{\mathrm{g}}$ & $668.33 \pm 0.88^{\mathrm{a}}$ & $701.00 \pm 0.58^{\mathrm{b}}$ & $757.33 \pm 0.88^{\mathrm{c}}$ & $911.67 \pm 0.88^{\mathrm{d}}$ & $1132.00 \pm 1.16$ & $1188.67 \pm 0.88^{f}$ \\
\hline
\end{tabular}

Figures are means \pm standard error. Means with the parallel superscript have no noteworthy variation at $p \leq 0.05$ level of significance. $\mu \mathrm{s} / \mathrm{cm}=\mathrm{microsecond} /$ centimeter

Effects of powdered $M$. oleifera seeds and alum on the $\mathrm{pH}$ of the domestic wastewater samples

The $\mathrm{pH}$ of the domestic wastewater (initial $\mathrm{pH}$ ) at the point of collection was high at 8.5 for Jibowu hostel and the lowest $\mathrm{pH}$ was recorded at 3.06 for Adeniyi hostel. The $\mathrm{pH}$ of the wastewater with $2 \mathrm{~g}$ of powdered M. oleifera seeds was high at 7.36 while the lowest $\mathrm{pH}$ was observed to be 6.34 for Adeniyi hostel. The $\mathrm{pH}$ of the wastewater dropped with $4 \mathrm{~g}$ of powdered M. oleifera seeds introduced at 7.02 for both Abiola and Akindeko hostels while the lowest $\mathrm{pH}$ was recorded at 6.23 for Adeniyi hostel. The $\mathrm{pH}$ of the wastewater dropped further with $6 \mathrm{~g}$ of powdered M. oleifera seeds introduced at 6.67 for Abiola hostel while the lowest $\mathrm{pH}$ was recorded at 6.00 for Jibowu hostel. The $\mathrm{pH}$ of the wastewater dropped even further with $2 \mathrm{~g}$ of alum introduced at 4.40 for Jibowu hostel while the lowest $\mathrm{pH}$ was recorded at 2.67 for Adeniyi hostel. The $\mathrm{pH}$ of the wastewater with $4 \mathrm{~g}$ of alum introduced at 4.30 for Jibowu hostel while the lowest $\mathrm{pH}$ was recorded at 2.16 for Adeniyi hostel. The $\mathrm{pH}$ of the wastewater with $6 \mathrm{~g}$ of alum introduced at 4.20 for Jibowu hostel while the lowest $\mathrm{pH}$ was recorded at 1.90 for Adeniyi hostel as demonstrated in Table 2.

Table 2 Effects of powdered M. oleifera seeds and alum on the $\mathrm{pH}$ of the domestic wastewater samples

\begin{tabular}{llllllll}
\hline $\begin{array}{l}\text { School } \\
\text { hostels }\end{array}$ & $\begin{array}{l}\text { Initial } \\
\text { pH }\end{array}$ & \multicolumn{2}{l}{$\begin{array}{l}\text { After treatment } \\
\text { oleifera } \text { seeds }\end{array}$} & with & powdered $\boldsymbol{M}$. & After treatment with alum & \\
\hline & & $2 \mathrm{~g}$ & $4 \mathrm{~g}$ & $6 \mathrm{~g}$ & $2 \mathrm{~g}$ & $4 \mathrm{~g}$ & $6 \mathrm{~g}$ \\
\cline { 2 - 8 } Jibowu & $8.53 \pm 0.09^{\mathrm{d}}$ & $7.00 \pm 0.12^{\mathrm{c}}$ & $6.40 \pm 0.88^{\mathrm{b}}$ & $6.00 \pm 0.18^{\mathrm{b}}$ & $4.40 \pm 0.12^{\mathrm{a}}$ & $4.30 \pm 0.06^{\mathrm{a}}$ & $4.20 \pm 0.07^{\mathrm{a}}$ \\
Jadesola & $6.67 \pm 0.09^{\mathrm{e}}$ & $7.36 \pm 0.12^{\mathrm{f}}$ & $6.25 \pm 0.15^{\mathrm{d}}$ & $6.20 \pm 0.67^{\mathrm{c}}$ & $3.19 \pm 0.00^{\mathrm{b}}$ & $3.03 \pm 0.01^{\mathrm{a}}$ & $2.92 \pm 0.03^{\mathrm{a}}$ \\
Akindeko & $4.78 \pm 0.01^{\mathrm{c}}$ & $7.24 \pm 0.01^{\mathrm{e}}$ & $7.02 \pm 0.02^{\mathrm{e}}$ & $6.50 \pm 0.08^{\mathrm{d}}$ & $2.82 \pm 0.01^{\mathrm{b}}$ & $2.70 \pm 0.07^{\mathrm{b}}$ & $2.55 \pm 0.07 \mathrm{a}$ \\
Adeniyi & $3.06 \pm 0.01^{\mathrm{d}}$ & $6.34 \pm 0.01^{\mathrm{f}}$ & $6.23 \pm 0.02^{\mathrm{f}}$ & $6.05 \pm 0.03^{\mathrm{e}}$ & $2.67 \pm 0.01^{\mathrm{c}}$ & $2.16 \pm 0.01^{\mathrm{b}}$ & $1.90 \pm 0.60^{\mathrm{a}}$ \\
Abiola & $5.05 \pm 0.01^{\mathrm{d}}$ & $7.05 \pm 0.01^{\mathrm{f}}$ & $7.02 \pm 0.01^{\mathrm{f}}$ & $6.67 \pm 0.10^{\mathrm{e}}$ & $3.75 \pm 0.02^{\mathrm{c}}$ & $3.27 \pm 0.01^{\mathrm{b}}$ & $3.01 \pm 0.02^{\mathrm{a}}$ \\
\hline
\end{tabular}

Figures are means \pm standard error. Means with the identical superscript have no major disparity at $p \leq 0.05$ level of significance

Effects of powdered M. oleifera seeds and alum on the turbidity of domestic wastewater samples

The turbidity at the point of collection of the wastewater was high at 0.958 NTU for Jibowu hostel and low at 0.128 NTU. The turbidity level of the wastewater with $2 \mathrm{~g}$ of powdered M. oleifera seeds was high at $0.101 \mathrm{NTU}$ for Adeniyi and the lowest turbidity was recorded at 0.066 NTU for Jadesola hostel. The turbidity level of the wastewater with $4 \mathrm{~g}$ of powdered M. oleifera seeds reduced at 0.096 NTU for Adeniyi hostel while the lowest turbidity was recorded at 0.057 NTU for Jadesola hostel. The turbidity level of the wastewater with $6 \mathrm{~g}$ of powdered M. oleifera seeds introduced also reduced at 0.088 NTU for Adeniyi hostel while the lowest turbidity was recorded at 0.029 NTU for Jadesola hostel. The turbidity level of the wastewater with $2 \mathrm{~g}$ of alum introduced was high at $0.212 \mathrm{NTU}$ for Jibowu hostel while the lowest turbidity was recorded at 0.049 NTU for Jadesola hostel. The turbidity level of the wastewater with $4 \mathrm{~g}$ of alum introduced reduced at $0.918 \mathrm{NTU}$ for Jibowu hostel while the lowest turbidity was recorded at 0.047 NTU for Jadesola and Akindeko hostels. The turbidity level of the wastewater with $6 \mathrm{~g}$ of alum introduced reduced further at 0.184 NTU for Jibowu hostel while the lowest turbidity was recorded at 0.039 NTU for Akindeko hostel which is lower than the WHO standard of 5 NTU as shown in Table 3. 
Table 3 Effects of powdered M. oleifera seeds and alum on the turbidity (NTU) of domestic wastewater samples

\begin{tabular}{lccccccc}
\hline $\begin{array}{l}\text { School } \\
\text { hostels }\end{array}$ & $\begin{array}{c}\text { Initial } \\
\text { turbidity }\end{array}$ & \multicolumn{2}{c}{ After treatment with powdered M. oleifera seeds } & \multicolumn{3}{c}{ After treatment with alum (NTU) } \\
\hline & & $2 \mathrm{~g}$ & $4 \mathrm{~g}$ & $6 \mathrm{~g}$ & $2 \mathrm{~g}$ & $4 \mathrm{~g}$ & $6 \mathrm{~g}$ \\
\hline Jibowu & $0.958 \pm 0.001^{\mathrm{d}}$ & $0.095 \pm 0.000^{\mathrm{b}}$ & $0.089 \pm 0.000^{\mathrm{ab}}$ & $0.029 \pm 0.000^{\mathrm{a}}$ & $0.212 \pm 0.000^{\mathrm{c}}$ & $0.198 \pm 0.000^{\mathrm{bc}}$ & $0.184 \pm 0.00^{\mathrm{bc}}$ \\
Jadesola & $0.102 \pm 0.000^{\mathrm{c}}$ & $0.066 \pm 0.000^{\mathrm{bc}}$ & $0.057 \pm 0.000^{\mathrm{b}}$ & $0.043 \pm 0.000^{\mathrm{a}}$ & $0.049 \pm 0.000^{\mathrm{a}}$ & $0.047 \pm 0.000^{\mathrm{a}}$ & $0.046 \pm 0.000^{\mathrm{a}}$ \\
Akindeko & $0.649 \pm 0.000^{\mathrm{c}}$ & $0.072 \pm 0.000^{\mathrm{b}}$ & $0.063 \pm 0.000^{\mathrm{b}}$ & $0.055 \pm 0.000^{\mathrm{ab}}$ & $0.059 \pm 0.000^{\mathrm{ab}}$ & $0.047 \pm 0.000^{\mathrm{ab}}$ & $0.039 \pm 0.000^{\mathrm{a}}$ \\
Adeniyi & $0.888 \pm 0.001^{\mathrm{e}}$ & $0.101 \pm 0.000^{\mathrm{d}}$ & $0.096 \pm 0.000^{\mathrm{cd}}$ & $0.088 \pm 0.000^{\mathrm{c}}$ & $0.089 \pm 0.000^{\mathrm{c}}$ & $0.077 \pm 0.000^{\mathrm{b}}$ & $0.070 \pm 0.000^{\mathrm{a}}$ \\
Abiola & $0.765 \pm 0.001^{\mathrm{f}}$ & $0.089 \pm 0.000^{\mathrm{bc}}$ & $0.081 \pm 0.000^{\mathrm{b}}$ & $0.071 \pm 0.000^{\mathrm{a}}$ & $0.121 \pm 0.000^{\mathrm{e}}$ & $0.101 \pm 0.000^{\mathrm{d}}$ & $0.090 \pm 0.000^{\mathrm{bc}}$ \\
\hline
\end{tabular}

Values are means \pm standard error. Means with the identical superscript have no considerable dissimilarity at $p \leq 0.05$ level of significance. Abs=Absorbance

Effects of powdered $M$. oleifera seeds and alum on bacterial count of domestic wastewater samples using nutrient agar

There was an increase in the initial bacterial count with $311 \mathrm{Cfu} / \mathrm{ml}$ recorded for Jibowu hostel while Abiola hostel had the lowest bacterial count of $176 \mathrm{Cfu} / \mathrm{ml}$ in the domestic wastewater on the point of collection. There was a considerate diminution of bacterial counts from the $2 \mathrm{~g}$ to $6 \mathrm{~g}$ of $M$. oleifera seed powder in subsequent treatment of the wastewater. The bacterial count of the wastewater reduced after the initial count with $2 \mathrm{~g}$ of $M$. oleifera seed powder at $199 \mathrm{Cfu} / \mathrm{ml}$ for Jibowu hostel while Abiola hostel had the lowest bacterial count of 56 $\mathrm{Cfu} / \mathrm{ml}$. Four ( $4 \mathrm{~g}$ ) of the M. oleifera seed powder introduced into the wastewater elicited $124 \mathrm{Cfu} / \mathrm{ml}$ for Jibowu hostel while Abiola hostel had the lowest count of $37 \mathrm{Cfu} / \mathrm{ml}$. Six $(6 \mathrm{~g})$ of the $M$. oleifera seed powder elicited $100 \mathrm{Cfu} / \mathrm{ml}$ for Jibowu hostel while Abiola hostel had the lowest count at $26 \mathrm{Cfu} / \mathrm{ml}$. Two (2 g) alum treatment of the wastewater elicited reduced bacterial count at $87 \mathrm{Cfu} / \mathrm{ml}$ for Adeniyi hostel and $29.33 \mathrm{cfu} / \mathrm{ml}$ for Abiola hostel. The bacterial count of the wastewater further reduced using $4 \mathrm{~g}$ of alum thereby eliciting $80 \mathrm{Cfu} / \mathrm{ml}$ for Adeniyi hostel while $16 \mathrm{Cfu} / \mathrm{ml}$ was recorded for Abiola hostel. Six $(6 \mathrm{~g})$ of the alum introduced for treatment brought about $62 \mathrm{Cfu} / \mathrm{ml}$ for Jibowu hostel and $6.33 \mathrm{Cfu} / \mathrm{ml}$ for Adeniyi hostel as demonstrated in Table 4.

\begin{tabular}{|c|c|c|c|c|c|c|c|}
\hline \multirow[t]{2}{*}{$\begin{array}{l}\text { School } \\
\text { hostels }\end{array}$} & \multirow[b]{2}{*}{ Before } & \multicolumn{3}{|c|}{$\begin{array}{l}\text { After treatment with powdered } M \text {. oleifera } \text { seeds } \\
\qquad(\mathrm{cfu} / \mathrm{ml})\end{array}$} & \multicolumn{3}{|c|}{$\begin{array}{l}\text { After treatment with alum } \\
(\mathrm{cfu} / \mathrm{ml})\end{array}$} \\
\hline & & $2 \mathrm{~g}$ & $4 \mathrm{~g}$ & $6 \mathrm{~g}$ & $2 \mathrm{~g}$ & $4 \mathrm{~g}$ & $6 \mathrm{~g}$ \\
\hline Jibowu & $311.00 \pm 0.58^{\mathrm{g}}$ & $199.67 \pm 0.89^{\mathrm{f}}$ & $124.33 \pm 1.20^{\mathrm{e}}$ & $100.00 \pm 0.57^{\mathrm{d}}$ & $81.00 \pm 0.57^{\mathrm{c}}$ & $73.33 \pm 0.89^{\mathrm{b}}$ & $62.00 \pm 0.57^{\mathrm{a}}$ \\
\hline Jadesola & $219.00 \pm 0.57^{\mathrm{f}}$ & $86.00 \pm 0.57^{\mathrm{e}}$ & $54.00 \pm 0.57^{\mathrm{d}}$ & $41.00 \pm 0.57^{\mathrm{c}}$ & $55.00 \pm 0.57^{\mathrm{d}}$ & $41.00 \pm 0.57^{\mathrm{b}}$ & $21.00 \pm 0.57^{\mathrm{a}}$ \\
\hline Akindeko & $278.33 \pm 1.20^{\mathrm{e}}$ & $139.00 \pm 0.57^{\mathrm{d}}$ & $75.00 \pm 1.15^{\mathrm{c}}$ & $41.00 \pm 0.57^{\mathrm{b}}$ & $76.00 \pm 0.57^{\mathrm{c}}$ & $42.00 \pm 0.57^{\mathrm{b}}$ & $21.00 \pm 0.57^{\mathrm{a}}$ \\
\hline Adeniyi & $202.00 \pm 1.15^{\mathrm{g}}$ & $102.00 \pm 0.57^{\mathrm{f}}$ & $90.33 \pm 0.88^{\mathrm{e}}$ & $75.00 \pm 0.57^{\mathrm{b}}$ & $87.00 \pm 0.57^{\mathrm{d}}$ & $80.00 \pm 0.57^{\mathrm{c}}$ & $61.00 \pm 0.88^{\mathrm{a}}$ \\
\hline Abiola & $176.00 \pm 0.57^{\mathrm{g}}$ & $56.00 \pm 0.57^{\mathrm{f}}$ & $37.00 \pm 0.33^{\mathrm{e}}$ & $26.00 \pm 0.57^{\mathrm{c}}$ & $29.33 \pm 0.33^{\mathrm{d}}$ & $16.00 \pm 0.57^{\mathrm{b}}$ & $6.33 \pm 0.57^{\mathrm{a}}$ \\
\hline
\end{tabular}

Values are means \pm standard error. Means with the parallel superscript have no noteworthy variation at $p \leq 0.05$ level of significance. $\mathrm{Cfu} / \mathrm{ml}=$ Colony forming unit per millimetre

Effects of powdered M. oleifera seeds and alum on lactose fermenters isolated from domestic wastewater samples using MacConkey agar

There was an increase in the initial lactose fermenter count before the addition of M. oleifera seed powder and alum with $177 \mathrm{Cfu} / \mathrm{ml}$ recorded for Adeniyi hostel while both Abiola and Jibowu hostels had the lowest lactose fermenter count of $76 \mathrm{Cfu} / \mathrm{ml}$ in the domestic wastewater on the point of collection. There was a considerate diminution of lactose fermenter count from the $2 \mathrm{~g}$ to $6 \mathrm{~g}$ of $M$. oleifera seed powder in subsequent treatment of the wastewater. The lactose fermenter count of the wastewater reduced after the initial count with $2 \mathrm{~g}$ of $M$. oleifera seed powder at $72 \mathrm{Cfu} / \mathrm{ml}$ for Adeniyi hostel while Abiola hostel had the lowest lactose fermenter count of $20 \mathrm{Cfu} / \mathrm{ml}$. Four ( $4 \mathrm{~g}$ ) of the M. oleifera seed powder introduced into the wastewater elicited $55 \mathrm{Cfu} / \mathrm{ml}$ for Adeniyi and Jadesola hostels while Abiola hostel had the lowest count of $17 \mathrm{Cfu} / \mathrm{ml}$. Six (6 g) of the M. oleifera seed powder elicited $41 \mathrm{Cfu} / \mathrm{ml}$ for Jadesola hostel while Abiola hostel had the lowest count at $11 \mathrm{Cfu} / \mathrm{ml}$. Two $(2 \mathrm{~g})$ alum treatment of the wastewater elicited reduced lactose fermenter count at $37 \mathrm{Cfu} / \mathrm{ml}$ for Jadesola hostel and $11 \mathrm{cfu} / \mathrm{ml}$ for Jibowu hostel. The lactose fermenter count of the wastewater further reduced using $4 \mathrm{~g}$ of alum thereby eliciting $18 \mathrm{Cfu} / \mathrm{ml}$ for Jadesola hostel while $7 \mathrm{Cfu} / \mathrm{ml}$ was recorded for Jibowu hostel. Six $(6 \mathrm{~g})$ of the alum introduced for the wastewater treatment brought about $15 \mathrm{Cfu} / \mathrm{ml}$ for Adeniyi hostel and $3.67 \mathrm{Cfu} / \mathrm{ml}$ for Jibowu hostel as displayed in Table 5.

Table 5 Effects of powdered M. oleifera seeds and alum on lactose fermenters isolated from domestic wastewater samples using MacConkey agar

\begin{tabular}{lccccccc}
\hline $\begin{array}{l}\text { School } \\
\text { hostels }\end{array}$ & \multicolumn{3}{c}{$\begin{array}{c}\text { After treatment with powdered } \text { M. oleifera } \\
\text { seeds }(\mathbf{c f u} / \mathbf{m l})\end{array}$} & \multicolumn{3}{c}{$\begin{array}{c}\text { After treatment with alum } \\
\text { (cfu/ml) }\end{array}$} \\
\hline & Before & $2 \mathrm{~g}$ & $4 \mathrm{~g}$ & $6 \mathrm{~g}$ & $2 \mathrm{~g}$ & $4 \mathrm{~g}$ & $6 \mathrm{~g}$ \\
Jibowu & $76.00 \pm 0.57^{\mathrm{g}}$ & $25.33 \pm 0.88^{\mathrm{f}}$ & $20.00 \pm 0.57^{\mathrm{e}}$ & $14.00 \pm 0.57^{\mathrm{d}}$ & $11.00 \pm 0.57^{\mathrm{c}}$ & $7.00 \pm 0.57^{\mathrm{b}}$ & $3.67 \pm 0.33^{\mathrm{a}}$ \\
Jadesola & $149.67 \pm 0.88^{\mathrm{g}}$ & $60.00 \pm 0.57^{\mathrm{f}}$ & $55.00 \pm 0.57^{\mathrm{e}}$ & $41.00 \pm 0.57^{\mathrm{d}}$ & $37.00 \pm 0.57^{\mathrm{c}}$ & $18.00 \pm 0.57^{\mathrm{b}}$ & $11.67 \pm 0.33^{\mathrm{a}}$ \\
Akindeko & $169.67 \pm 0.88^{\mathrm{f}}$ & $64.00 \pm 0.88^{\mathrm{e}}$ & $41.00 \pm 0.88^{\mathrm{d}}$ & $26.00 \pm 0.57^{\mathrm{c}}$ & $26.00 \pm 0.57^{\mathrm{c}}$ & $16.00 \pm 0.57^{\mathrm{b}}$ & $7.33 \pm 0.33^{\mathrm{a}}$ \\
Adeniyi & $177.00 \pm 0.57^{\mathrm{g}}$ & $72.00 \pm 0.57^{\mathrm{f}}$ & $55.00 \pm 0.57^{\mathrm{e}}$ & $40.33 \pm 0.33^{\mathrm{d}}$ & $26.63 \pm 0.88^{\mathrm{c}}$ & $11.00 \pm 0.57^{\mathrm{a}}$ & $15.00 \pm 0.57^{\mathrm{b}}$ \\
Abiola & $76.00 \pm 0.57^{\mathrm{e}}$ & $20.00 \pm 0.57^{\mathrm{d}}$ & $17.00 \pm 0.57^{\mathrm{c}}$ & $11.00 \pm 0.57^{\mathrm{b}}$ & $16.00 \pm 0.57^{\mathrm{c}}$ & $11.00 \pm 0.57^{\mathrm{b}}$ & $6.00 \pm 0.57^{\mathrm{a}}$ \\
\hline Figures are means \pm standard error. Means with equivalent superscript have no major disparity at $p \leq 0.05$ level of significance. \\
Cfu/ml= Colony forming unit per millimeter
\end{tabular}

Effects of powdered M. oleifera seeds and alum on fungal count in domestic wastewater samples

There was an initial increase in the fungal count before the addition of $M$. oleifera seed powder and alum with the highest fungal count of $45 \mathrm{Sfu} / \mathrm{ml}$ recorded for Akindeko hostel while Jibowu hostel had the least fungal count of $22 \mathrm{Sfu} / \mathrm{ml}$ in the domestic wastewater on the point of collection. There was subsequent reduction of fungal counts from the $2 \mathrm{~g}$ to $6 \mathrm{~g}$ of $M$. oleifera seed powder introduced for the wastewater treatment. The lactose fermenter count of the wastewater reduced after the initial count with $2 \mathrm{~g}$ of $M$. oleifera seed powder 
at $26 \mathrm{Sfu} / \mathrm{ml}$ for Akindeko hostel while Abiola hostel had the lowest fungal count of $13 \mathrm{Sfu} / \mathrm{ml}$. Four $(4 \mathrm{~g})$ of the M. oleifera seed powder introduced into the wastewater elicited the highest fungal count of $18 \mathrm{Sfu} / \mathrm{ml}$ for Akindeko hostel while Jibowu hostel had the lowest fungal count of $7 \mathrm{Cfu} / \mathrm{ml}$. Six $(6 \mathrm{~g})$ of the $M$. oleifera seed powder elicited a further reduced fungal count of $11 \mathrm{Sfu} / \mathrm{ml}$ for Akindeko hostel and $5 \mathrm{Sfu} / \mathrm{ml}$ for Jibowu hostel. Two $(2 \mathrm{~g})$ alum treatment of the wastewater elicited reduced fungal count at $19 \mathrm{Sfu} / \mathrm{ml}$ for Akindeko hostel and 7
$\mathrm{Sfu} / \mathrm{ml}$ for Jibowu hostel. The fungal count of the wastewater further reduced using $4 \mathrm{~g}$ of alum thereby eliciting $15 \mathrm{Sfu} / \mathrm{ml}$ for Akindeko hostel while $5 \mathrm{Sfu} / \mathrm{ml}$ was recorded for Jibowu hostel. Six $(6 \mathrm{~g})$ of the alum introduced for the wastewater treatment brought about $10 \mathrm{Sfu} / \mathrm{ml}$ for Akindeko hostel and 2.0 $\mathrm{Sfu} / \mathrm{ml}$ for Jibowu hostel as illustrated in Table 6.

Table 6 Effects of powdered M. oleifera seeds and alum on fungal count in domestic wastewater samples

\begin{tabular}{|c|c|c|c|c|c|c|c|}
\hline \multirow[t]{2}{*}{$\begin{array}{l}\text { School } \\
\text { hostels }\end{array}$} & & \multicolumn{3}{|c|}{$\begin{array}{l}\text { After treatment with powdered } M \text {. oleifera } \\
\text { seeds }(\mathrm{sfu} / \mathrm{ml})\end{array}$} & \multicolumn{3}{|c|}{$\begin{array}{l}\text { After treatment with alum } \\
(\mathrm{sfu} / \mathrm{ml})\end{array}$} \\
\hline & Before & $2 \mathrm{~g}$ & $4 \mathrm{~g}$ & $6 \mathrm{~g}$ & $2 \mathrm{~g}$ & $4 \mathrm{~g}$ & $6 \mathrm{~g}$ \\
\hline Jibowu & $22.67 \pm 0.88^{\mathrm{d}}$ & $15.00 \pm 0.57^{\mathrm{c}}$ & $7.00 \pm 0.57^{b}$ & $5.00 \pm 0.57^{\mathrm{b}}$ & $7.00 \pm 0.57^{\mathrm{b}}$ & $5.00 \pm 0.57^{\mathrm{b}}$ & $2.00 \pm 0.57^{\mathrm{a}}$ \\
\hline Jadesola & $31.00 \pm 0.57^{\mathrm{f}}$ & $21.00 \pm 0.57^{\mathrm{e}}$ & $12.00 \pm 0.57^{\mathrm{d}}$ & $9.00 \pm 0.57^{\mathrm{bc}}$ & $10.33 \pm 1.20^{\mathrm{cd}}$ & $8.00 \pm 0.57^{\mathrm{ab}}$ & $6.00 \pm 0.57^{\mathrm{a}}$ \\
\hline Akindeko & $45.33 \pm 0.88^{\mathrm{e}}$ & $26.00 \pm 0.57^{\mathrm{d}}$ & $18.00 \pm 0.57^{\mathrm{c}}$ & $11.00 \pm 0.57^{\mathrm{a}}$ & $19.00 \pm 0.88^{c}$ & $15.00 \pm 0.57^{\mathrm{b}}$ & $10.00 \pm 1.15^{\mathrm{a}}$ \\
\hline Adeniyi & $28.00 \pm 0.57^{\mathrm{e}}$ & $17.00 \pm 0.57^{\mathrm{d}}$ & $16.00 \pm 0.57^{\mathrm{d}}$ & $9.00 \pm 0.88^{\mathrm{c}}$ & $8.00 \pm 0.57^{\mathrm{c}}$ & $6.00 \pm 0.57^{\mathrm{b}}$ & $3.00 \pm 0.57^{\mathrm{a}}$ \\
\hline Abiola & $24.00 \pm 0.57^{\mathrm{e}}$ & $13.00 \pm 0.57^{\mathrm{d}}$ & $7.67 \pm 0.33^{\mathrm{b}}$ & $6.00 \pm 0.57^{\mathrm{a}}$ & $11.00 \pm 0.57^{\mathrm{c}}$ & $9.00 \pm 0.57^{\mathrm{b}}$ & $5.00 \pm 0.57^{\mathrm{a}}$ \\
\hline
\end{tabular}

Figures are means \pm standard error. Means with the same superscript have no significant difference at $p \leq 0.05$ level of significance. $\mathrm{Sfu} / \mathrm{ml}=$ Spore-forming unit per millimeter

\section{Bacterial organisms isolated from the domestic wastewater samples}

Three of the bacteria isolated after treatment of the wastewater samples with $M$. oleifera seeds were biotechnologically-identified after the determination of their biochemistry and were successfully submitted into the NCBI gene bank including; Bacillus cereus strain mkbk 1 with accession number MT199666, Pseudomonas aeruginosa strain mkbk 2 with accession number MT199667 and
Enterobacter ludwigii strain mkbk 3 with accession number MT199668 as displayed in Table 7 excluding Escherichia coli, and Bacillus subtilis which were identified via the nominal biochemical characterization with results compared with Bergey's manual of systematic bacteriology (Don et al., 2006) for presumptive identification as juxtaposed in Table 8 .

Table 7 Molecular identification of the domestic wastewater bacterial isolates

\begin{tabular}{|c|c|c|c|c|c|}
\hline $\begin{array}{l}\text { Isolate } \\
\text { codes }\end{array}$ & $\begin{array}{l}\text { Biochemical } \\
\text { Identity }\end{array}$ & $\begin{array}{l}\text { Molecular } \\
\text { identity }\end{array}$ & $\begin{array}{l}\text { Percentage } \\
\text { similarity }\end{array}$ & Strain number & $\begin{array}{l}\text { NCBI-assigned } \\
\text { Accession number }\end{array}$ \\
\hline Ba & Bacillus cereus & Bacillus cereus & $99.31 \%$ & Mkbk 1 & MT199666 \\
\hline $\mathbf{P a}$ & Pseudomonas aeruginosa & Pseudomonas aeruginosa & $96.93 \%$ & Mkbk 2 & MT199667 \\
\hline El & Enterobacter ludwigii & Enterobacter ludwigii & $97.43 \%$ & Mkbk 3 & MT199668 \\
\hline
\end{tabular}

Keys: Ba- Bacillus cereus; El- Enterobacter ludwigii; Pa- Pseudomonas aeruginosa

Table 8 Biochemistry of bacterial isolates from the domestic wastewater samples

\begin{tabular}{|c|c|c|c|c|c|c|c|c|c|c|c|c|c|}
\hline \multirow[b]{2}{*}{ 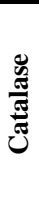 } & \multirow[b]{2}{*}{ 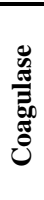 } & \multirow[b]{2}{*}{ 啻 } & \multirow[b]{2}{*}{$\stackrel{N}{\mathbb{N}}$} & \multirow[b]{2}{*}{$\underset{\Xi}{\mathscr{\Xi}}$} & \multirow[b]{2}{*}{$\stackrel{\frac{0}{0}}{\text { อ }}$} & \multirow[b]{2}{*}{ 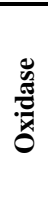 } & \multicolumn{4}{|c|}{ Sugar Fermentation } & \multirow[b]{2}{*}{ 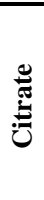 } & \multirow[b]{2}{*}{ Ðేٍ } & \multirow[b]{2}{*}{ 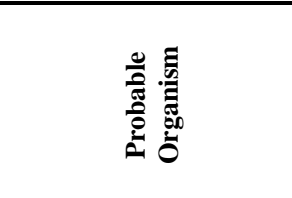 } \\
\hline & & & & & & & 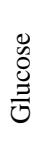 & 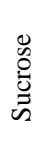 & 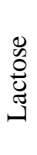 & $\begin{array}{l}\bar{O} \\
\stackrel{\Xi}{\Xi} \\
\text { 芯 }\end{array}$ & & & \\
\hline+ & - & + & + & - & + & - & + & + & + & + & - & -ve rods & Escherichia coli \\
\hline - & - & - & - & - & - & - & + & + & + & + & - & -ve rods & Enterobacter ludwigii \\
\hline+ & - & + & - & - & - & + & - & + & - & + & + & -ve rods & Pseudomonas aeruginosa \\
\hline+ & + & + & - & NA & - & - & + & + & - & - & + & +ve rods & Bacillus cereus \\
\hline+ & + & + & - & NA & - & - & + & + & - & - & + & +ve rods & Bacillus subtilis \\
\hline
\end{tabular}

Keys: + = positive; - = negative; NA - Not applicable 


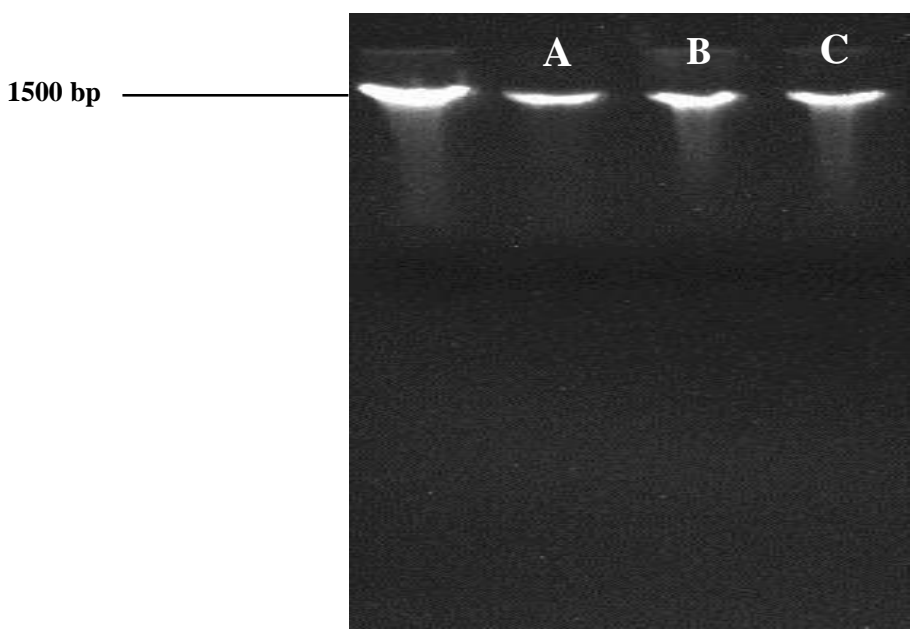

Plate 1 The 16S rRNA gene amplified by polymerase chain reaction of the test bacterial isolates Bacillus cereus (A), Pseudomonas aeruginosa (B), Enterobacter ludwigii (C)

\section{Fungal organisms enumerated from the domestic wastewater samples}

The morphological traits of fungal organisms isolated from the wastewater samples are Aspergillus flavus, A. niger, A. fumigatus, Candida parapsilosis, Fusarium oxysporum, and Penicillium citrinum as displayed in Table 9.

Table 9 Macro and micro-morphological features of fungal organisms from the domestic wastewater samples

\begin{tabular}{|c|c|c|}
\hline Macroscopic features & Microscopic features & Probable fungal organisms \\
\hline $\begin{array}{l}\text { Black mycelia growth } \\
\text { Greyish blue colonies } \\
\text { Light green and powdery } \\
\text { growth } \\
\text { Yellow and cottony-like growth } \\
\text { Whitish mycelia growth } \\
\text { Yellow pink creamy colonies }\end{array}$ & $\begin{array}{c}\text { Hypha is septate. Possess simple upright conodiophores that } \\
\text { terminates in a globosely } \\
\text { Versicular shape with rough uniseptate sporangiosphore } \\
\text { Long, erect septate and condiophores } \\
\text { Long erect conidiophores with round-shaped conidia } \\
\text { Round white-phase and elongated, opaque-phase } \\
\text { Cylindrical to ovoid conidia with curved septate } \\
\text { conidiophores }\end{array}$ & $\begin{array}{l}\text { Aspergillus niger } \\
\text { Aspergillus fumigatus } \\
\text { Aspergillus flavus } \\
\\
\text { Penicillium citrinum } \\
\text { Candida parasilopsis } \\
\text { Fusarium oxysporum }\end{array}$ \\
\hline
\end{tabular}

\section{DISCUSSION}

This study was carried out to evaluate the bio-flocculating and antimicrobial activities of powdered $M$. oleifera seeds and alum for the treatment of domestic wastewater samples obtained from five different school hostels as sampling points at Federal University of Technology, Akure (FUTA). This study revealed conductivity decreased generally as aluminum sulfate (alum) and powdered $M$. oleifera seeds showed similar trend of decreasing conductivity. However, powdered $M$. oleifera seeds showed a lower conductivity than alum which implies that it contains less impurities than alum. There was a decrease in the conductivity in this study carried out which is analogous with observations of the study carried out by Hendrawati et al. (2016) who also noticeably observed a decrease in the conductivity of water samples used. Tunggolou and Payus, (2017); Bakare, (2016) did not observe any significant difference between the initial electrical conductivity and after treatment of the wastewater samples with powdered $M$. oleifera; this might be due to the removal of the epicarp on $M$. oleifera seeds before using it for the treatment of the wastewater samples. This investigation further revealed that powdered $M$. oleifera seeds at $2 \mathrm{~g}$ were most effectual for the removal of impurities been significantly different from other concentration used. The initial decrease in electrical conductivity of domestic wastewater that was treated with powdered M. oleifera seeds could have been as a result of the ions formed during the coagulation process, formation of the ions may also contribute to the overall conductivity. Another reason that might contribute to the increased conductivity would be the dissociation of the inorganic compounds in alum which results in the wastewater's ability to conduct large electric current; this was also observed by Tunggolou and Payus, (2017). The recommended $\mathrm{pH}$ range by World Health Organization (WHO) for wastewater discharged into water bodies or land is $5.0-8.0$. The optimum $\mathrm{pH}$ obtained using powdered $M$. oleifera seeds was $6.00-7.38$ and in line with the recommended standard WHO, (2006). This further elaborated the fact that the lowest concentration of powdered $M$. oleifera seeds brought the $\mathrm{pH}$ to a neutral value and as the concentrations increased, it gradually moved to a slightly acidic value, this was the same trend noticed by Maduabuchi, (2018). The change in the $\mathrm{pH}$ reading when seeds were used results in the final $\mathrm{pH}$ reading being within the permitted range of standard for domestic wastewater. Sasikala and Muthuraman, (2016) stated that for the coagulation efficiency using M. oleifera, the $\mathrm{pH}$ should either be acidic $(<6)$ or should be alkaline $(>11)$, their coagulation efficiency is particularly good due to the domination of positive charges on the amino acids that build the protein molecule as also corroborated in this study.

Hendrawati et al. (2016) also observed similar trend in their study carried out on domestic wastewater treatment and expatiated on the fact that wastewater became slightly alkaline due to the ability of $M$. oleifera seeds to present its cationic water-soluble protein found in its skins and seeds, this causes the acceptance of protons by the alkaline amino acid to release the hydroxyl group which makes the solution slightly acidic. Opposing this trend was Ewan et al. (2009) who noticed that the $\mathrm{pH}$ did not change significantly after treatment with powdered $M$. oleifera seeds; but this might be due to the removal of the seed oil present in the seed and using the seed cake for water treatment. Alum had the lowest $\mathrm{pH}$ which was below the recommended standard due to alkalinity consumption during hydrolysis by the coagulant. This is consistent with the results obtained from Jowa and Mguni, (2005) where they stated that alum was more acidic and hence its consumption of alkalinity is higher to prevent acidity of water samples in their study. This further buttress the suggestion earlier raised by Ahmad et al. (2018) who noted elevated residues of aluminium remnants in treated domestic wastewater with a tendency for increased apprehension on human wellbeing due to its acidity.

The initial absorbance obtained showed that the wastewater samples were quite high which implied high turbidity. The mechanism responsible for reduction of turbidity by powdered $M$. oleifera seeds were due to the ability of the powdered seeds to adsorb both positively and negatively-charged colloids and neutralize their charge in the wastewater samples as supported by Ndagengesere $\boldsymbol{e t}$ al. (2015). The result obtained from this study meet the domestic wastewater quality standard recommended by World Health Organization (WHO), (2006) with the lowest turbidity obtained at a concentration of $6 \mathrm{~g}$ which was significantly different from alum also at $6 \mathrm{~g}$. Bakare, (2016) also observed a $90 \%$ decrease in turbidity from the use of powdered $M$. oleifera seeds. The study carried out by Tunggolou and Payus, (2017) also showed that $M$. oleifera was more effective at reducing turbidity than alum. The ability of alum to reduce turbidity of the wastewater samples is based on aluminum salts been hydrolyzed to produce cationic species responsible for absorbing negatively-charged colloidal particles and also neutralizing their charges as destabilization of the particles occur as reported by Vinoth et al. (2012).

Reduced microbial population with powdered $M$. oleifera seeds at $4 \mathrm{~g}$ may be due to the presence of some active biochemical agents in M. oleifera seeds according 
to Aromolaran, (2013). From the comparism of the microbial population before and after treatment, it was observed that $M$. oleifera reduced the microbial population (bacteria and fungi); although, the microbial population for $M$. oleifera at $6 \mathrm{~g}$ was still higher than that noticed in alum at $4 \mathrm{~g}$ quantity. This might be due to the compounds contained in the M. oleifera seeds from which some may serve as growth factors for microorganisms; so after bio-flocculation, organisms may proliferate using nutrients supplied by M. oleifera seeds. Alum was able to reduce the microbial load more significantly; this may suggest it has the ability as a chemical flocculant to alter the water $\mathrm{pH}$, a factor necessary for growth of microorganisms and hence less microbial population after treatment as opined by Madsen et al. (2017). The high bacterial and fungal count of the domestic wastewater samples in this study indicates a very high presence of different microbial contamination due to the presence of organic residues and partly due to human-related activities inherent in the wastewater samples in this study as supported by Olalemi $\boldsymbol{e t}$ al. (2021) who correlated the faecal bacterial count of hospital wastewater with diarrheagenic faecal samples.

The results of the bacterial consortium enumerated from the domestic wastewater samples in this study are consistent with Brown et al. (2012) who confirmed the occurrence of coliforms, Clostridia, Enterococcus, lacto bacilli, Micrococci, Proteus, Pseudomonas, Streptococcus, Staphylococcus species while the outcome/findings of fungal organisms isolated from the domestic wastewaters are also analogous to Liu et al. (2017) who also affirms the presence of Candida, Geotrichum, Geotrichum candidum, Aspergillus, and Penicillium spp. Putt and Kleber, (1995); (Photos-Jones, 2018) also affirms the occurrence of Gram positive and Gram negative bacterial consortia including Enterococcus faecalis, E. faecium, Escherichia coli, Klebsiella pneumoniae and Pseudomonas aeruginosa respectively from contaminated domestic waters which is as well evident in this study.

\section{CONCLUSION}

Wastewater treatment using powdered M. oleifera seeds revealed its efficiency in aiding maximum suspended materials removal and reduction of $\mathrm{pH}$ from alkalinity to acidity together with alum. The seeds displayed effective coagulation properties which is efficient in reducing the presence of microorganisms in domestic wastewaters as evident in this study. Moringa oleifera seed powder was also efficacious in improving the physicochemical profile of the wastewater in this study compared to alum. The powdered $M$. oleifera seeds has been tested and confirmed to be an effective material for the bacteriological and fungal treatment of domestic wastewater. The findings of this study suggest that the bio-flocculating ability of powdered $M$. oleifera seeds accentuated better antimicrobial efficacy of $M$. oleifera over alum as a proviso to the blend of powdered $M$. oleifera seeds and alum for the treatment of domestic wastewaters. To ensure environmental safety, it is hereby recommended domestic wastewater should be treated before releasing into the environment to reduce environmental pollution. M. oleifera should be used for the treatment of any type of wastewater before their release to the environment. Appropriate sewer system should be built by water-regulatory bodies to ease the treatment of the domestic wastewaters especially in the developing countries.

Authors' inputs: OOO designed the study. DEA developed the methodology and acquire the data, analyse the data and interpreted the data. MTB wrote the manuscript, OOO corrected the manuscript. MTB reviewed and revised the manuscript. OOO provided administrative support and aptly supervised the study. All authors read and approved the final manuscript.

Conflict of Interest: The authors have no conflict of interest to declare.

\section{REFERENCES}

MOHAMED, H. H., MOHAMED A. G. 2016. Proceedings of the World Congress on Civil, Structural, and Environmental Engineering (CSEE'16) Prague, Czech Republic - March 30 - 31, 2016 Paper No. AWSPT 111. https://doi:10.11159/awspt16.111

MANAGING THE ENVIRONMENTAL IMPACTS OF DOMESTIC WASTEWATER. September (MEIDW) 2018. Independent assurance report to Parliament 2018-19: 10

DUNCAN, M. 2003. Domestic wastewater treatment in developing countries. Earthscan, 22883 Quicksilver Drive, Sterling, VA 20166-2012, USA.
THAKUR, S. S AND CHOUBEY, S. (2014). Assessment of coagulation efficiency of Moringa oleifera and Okra for treatment of turbid water. Archives of Applied Science Research. 6(2), 24-30.

KATAYON, S., MEGAT MOHD NOOR, M. J., ASMA, M., ABDUL GHANI, L.A., THAMER, A.M., AZNI, I., AHMAD, J., KHOR, B.C., SULEYMAN, A.M. (2006). Effects of storage conditions of Moringa oleifera seeds on its performance in coagulation. Bio-resource Technology. 97, 1455-1460.

SASIKALA, S., \& MUTHURAMAN, G. 2016. A Laboratory Study for the Treatment of Turbidity and Total Hardness Bearing Synthetic Wastewater/Ground Water Using Moringa oleifera. Industrial Chemistry. 2, (1). https://doi.org/10.4172/2469-9764.1000112

AMAGLOH, F. K., \& BENANG, A. 2009. Effectiveness of Moringa oleifera Seed as Coagulant for Water Purification. African Journal of Agricultural Research 4 (1), 119-123.

BINA, B. (1991)a. Investigation into the use of natural plant coagulant in the removal of bacteria and bacteriophage from turbid waters. $\mathrm{Ph} \mathrm{D}$ thesis, University of Newcastle upon Tyne, United Kingdom.

FOLKARD, G. AND SUTHERLAND, T. (2001). The use of Moringa oleifera as a natural coagulant for water and waste water treatment", Department of engineering, University of Leicester, UK.

MANGALE, S. M., CHONDE, S. G., JADHAV, A. S. RAUT, P. D. 2012. Study of Moringa oleifera (Drumstick) seed as natural Absorbent and Antimicrobial agent for River water treatment. Journal of National Production and Plant Resource. 2 (1), 89-100.

ADENIRAN, K. A., AKPENPUUM, T. D., AKINYEMI, B. A., WASIU, R. A. (2017). Effectiveness of Moringa oleifera seed as a coagulant in domestic wastewater treatment. African Journal of Science, Technology, Innovation and Development. 2017, 1-6. http://dx.doi.org/10.1080/20421338.2017.1327475

AKHTAR, M., HASANY, S. M., BHANGER, M. I. 2007 Sorption potential of Moringa oleifera pods for the removal of organic pollutants from aqueous solutions. Journal of Hazardous Materials. 141, 546-556. https://doi.org/10.1016/j.jhazmat.2006.07.016

SUAREZ, M., ENTENZA, J. M., DOERRIES, C., 2003. Expression of a plantderived peptide harboring water-cleaning and antimicrobial activities. Biotechnology and Bioengineering, 81, 13-20. https://doi.org/10.1002/bit.10550

MUYIBI, S. A., \& EVISON, L. M. 1995. Moringa oleifera seeds for softening hardwater. Water Research, 29(4), 1099-1104. https://doi.org/10.1016/00431354(94)00250-b

JABEEN, R., SHAHID, M., JAMIL, A. 2008. Microscopic evaluation of the antimicrobial activity of seed extracts of Moringa oleifera. Pakistan Journal of Botany. 40(4), 1349-1358.

PUTT, M., \& KLEBER, C. 2008. Effect of aluminum concentration on dental caries formation in the rat. Oral Diseases, 1(2), 80-85. https://doi.org/10.1111/j.1601-0825.1995.tb00164.x

PHOTOS-JONES, E. 2018. From mine to apothecary: an archaeo-biomedical approach to the study of the Greco-Roman litho-therapeutics industry. World Archaeology, 50(3), 418-433. https://doi.org/10.1080/00438243.2018.1515034

MENEGHEL A. P., GONCALVES A. C., JR, FERNANDA, R. 2013. Biosorption of cadmium from water using Moringa (Moringa oleifera Lam.) seeds. Water, Air and Soil Pollution 224, 1383

VIKASHNI, N., MATAKITE, M., KANAYATHU, K (2012). Water purification using Moringa oleifera and other locally available seeds in Fiji for heavy metal removal. International Journal of Applied Science and Technology. 5, 125-129

MANGALE, S.M., CHONDE, S.G., RAUT, P.D (2012). Use of Moringa oleifera (drumstick) seed as natural absorbent and an antimicrobial agent for ground water treatment. Research Journal on Recent Science. 1, 31-40

ARNOLDSSON, E., BERGMAN, M., MATSINHE, N (2008). Assessment of drinking water bark extracts of Moringa oleifera in reducing bacterial load in water. International Journal of Advance Research. 4, 124-130

BINA, B., MEHDINEJAD, M.H., GUNNEL, D (2010)b. Effectiveness of Moringa oleifera coagulant protein as natural coagulant aid in removal of turbidity and bacteria from turbid waters. World Academy of Science and Engineering Technology. 4, 7-28

EMAN, N.A., TAN, C.S., MAKKY, E. A 2014. Impact of Moringa oleifera cake residue application on wastewater treatment: a case study. Journal of Water Resource Protection. 6, 677-687

SRIVASTAVA, M (2014). The health benefits of Moringa oleifera plant. Live Strong Foundation. http://www.livestrong.com/article/ 431418-the-health-benefits-of-moringa-oleifera-plants/. Accessed 26 Sept 2014 
JABEEN, R., SHAHID, M., JAMIL, A 2008. Microscopic evaluation of the antimicrobial activity of seed extracts of Moringa oleifera.

Pakistan Journal of Botany. 40, 1349-1358

ISHAK, W. M. F. W., JAMEK, S., JALANNI, N.A., 2001. Isolation and identification of bacteria from activated sludge and compost municipal solid waste treatment system. International Conference on Biology and Environmental Chemistry. 24, 450-454.

ZAVED, H.K., RAHMAN, M.M., RAHMAN, A., 2008. Isolation and characterization of effective bacteria for solid waste degradation for organic manure. KMIT Science and Technology Journal. 8 (2), 844-855.

AHMAD, H. J., SULE, A., IBRAHIM, M. L., AB AZIZ A. L., IBRAHIM, U. (2018). Wastewater Treatment Using Alum, theCombinations of Alum-Ferric Chloride, Alum-Chitosan, Alum-Zeolite and Alum- Moringa Oleifera as Adsorbent and Coagulant. International Journal of Engineering Management. 2 (3), 67-75. https://doi.org/10.11648/j.ijem.20180203.13

BALA, T., ARMSTRONG, G., LAFFIR, F., THORNTON, R. (2011). Titaniasilver and alumina-silver composite nanoparticles: novel, versatile synthesis, reaction mechanism and potential antimicrobial application. Journal of Colloid and Interface Science. 356, 395-403

BROWN, G. D., DAVID, W. D., NEIL, A. R. G., 2012. Hidden killers: human fungal infections. Science and Translational Medicine. 4:165. https://doi.org/10.1126/scitranslmed.3004404

LIU, J., LI, J., TAO, Y., SELLAMUTHU, B., \& WALSH, R. 2016. Analysis of bacterial, fungal and archaeal populations from a municipal wastewater treatment plant developing an innovative aerobic granular sludge process. World Journal of Microbiology and Biotechnology, 33(1), https://doi.org/10.1007/s11274-0162179-0

AOAC (ASSOCIATION OF OFFICIAL ANALYTICAL CHEMISTS) Official Methods of Analysis of Official Chemists International 19th Edition Official Method of Analysis of the AOAC Arlington, Virginia USA. (2012).

FAWOLE, M. O., OSO, B. A. Characterization of Bacteria In: Laboratory Manual of Microbiology. Spectrum Book Ltd., Ibadan, Nigeria, 2001.

FAWOLE, M. O., OSO, B. A. Characterization of Bacteria In: Laboratory Manual of Microbiology, Spectrum Book Ltd., Ibadan, Nigeria, 2008.

GURAKAN, G. C., AKSOY, C., OGEL, Z. B., 2008. Differentiation of Salmonella typhymurium from Salmonella enteritidis and other Salmonella serotypes using random amplified polymorphic DNA analysis. Poultry Science. 87, 1068-1074.

ESCHBACH, S., HOFMANN, C., MAERZ, M., MAIER, U.-G. ., \& SITTE, P. 1990. Molecular Cloning. A Laboratory Manual. 2. Auflage. HRSG. VON J. SAMBROOK, E. F. FRITSCH, T. MANIATIS, Cold Spring Harbor Laboratory Press, Cold Spring Harbour 1989, \$ 115. ISBN 0-87969-309-6. Biologie in Unserer Zeit, 20(6), 285-285. https://doi.org/10.1002/biuz.19900200607

DON, J. B., JAMES, T. S., NOEL, R. K. In: Bergey's Manual of Systematic Bacteriology (Volume 2, Parts Aâ $\square$ "C, 2nd Edition). (2006). FEMS Immunology \& Medical Microbiology, 46(3), 476-476. https://doi.org/10.1111/j.1574695x.2005.00055.x

HENDRAWATI, R. S., INDRA, R. Y., ETI, R., 2016. The use of Moringa oleifera seed powder as coagulant to improve the quality of wastewater and groundwater. Earth Environmental Science. 31, 5. https://doi:10.1088/1755$\underline{1315 / 31 / 1 / 012033}$

TUNGGOLOU, J., \& PAYUS, C. 2017. Application of Moringa oleifera Plant as Water Purifier for Drinking Water Purposes. Journal of Environmental Science and Technology, 10(5), 268-275. https://doi.org/10.3923/jest.2017.268.275

BAKARE, B. F. 2016. An Investigation of Moringa Oleifera Seed Extract as a Natural Coagulant in Water Treatment. Proceedings of the World Congress on Engineering and Computer Science 2, WCECS. ISSN: 2078-0958 (Print); ISSN: 2078-0966 (Online)

WORLD HEALTH ORGANIZATION (WHO) Regional Office for the Eastern Mediterranean Regional Centre for Environmental Health Activities (CEHA) (2006). A compendium of standards for wastewater reuse in the Eastern Mediterranean Region.

MADUABUCHI, M. N. 2018. Bacteriological treatment of waste water from paint industry using Moringa oleifera seed. International Journal of Waste Research. 8(2), 337. https://doi.org/10.4172/2252-5211.1000337

EMAN, A. N., MUYIBI, S. A., SALLEH, H. M., ALAM, M. Z., \& SALLEH, M. R. M. 2010. Production of Natural Coagulant from Moringa Oleifera Seed for Application in Treatment of Low Turbidity Water. Journal of Water Resource and Protection, 02(03), 259-266. https://doi.org/10.4236/jwarp.2010.23030
JOWA, T., Mguni, L. L. 2015. Treatment of low turbidity water using PolyAluminium Chloride (PAC) and Recycled Sludge: Case study Chinhoyi. Zimbabwean Journal of Science and Technology. 10, 101-108.

NDAGENGESERE, A., NARASIAH, K., TALBOT, B. 2015. Active agents and mechanism of coagulation of turbid water using Moringa oleifera. Water Research. 29(2), 95-102. https://doi.org/10.1016/0043-1354(94)00161-Y

VINOTH, B., MANIVASAGAPERUMAL, R., BALAMRUGAN, S. 2012. Phytochemical analysis and antibacterial activity of Moringa oleifera lam. International Journal of Research in Biological Science. 2(3), 98-102.

AROMOLARAN, O. 2013. Effect of Moringa oleifera seeds on bacterial quality of drinking water in rural communities of Ondo, South-Western Nigeria. Ife Journal of Science. 15 (3), 631-635.

MADSEN, M. J., SCHLUNDT, J. E., OMER-EL, E. F. 2017. Effect of $M$. oleifera seeds on bacteria concentration. Journal of Tropical Medicine and Hygiene 90, 101-109.

OLALEMI, A., OLADEJO, B., AND BAYODE, M. 2021. Correlation between faecal indicator bacteria in diarrheagenic stools and hospital wastewaters: implication on public health. African Journal of Clinical and Experimental Microbiology. 22(2), 234-243. https://dx.doi.org/10.4314/ajcem.v22i2.16 